\title{
Article \\ Three New Isoprenylated Flavones from Artocarpus chama Stem and Their Bioactivities
}

\author{
Sukanya Dej-adisai ${ }^{1, *}$, Kedsaraporn Parndaeng ${ }^{1}$, Chatchai Wattanapiromsakul ${ }^{1}$ and Jae Sung Hwang ${ }^{2}$ (I) \\ 1 Department of Pharmacognosy and Pharmaceutical Botany, Faculty of Pharmaceutical Sciences, \\ Prince of Songkla University, Hat Yai, Songkhla 90112, Thailand; kedsarapon.p@gmail.com (K.P.); \\ chatchai.w@psu.ac.th (C.W.) \\ 2 Department of Genetic Engineering \& Graduate School of Biotechnology, College of Life Sciences, \\ Kyung Hee University, Youngin 17104, Korea; jshwang@khu.ac.kr \\ * Correspondence: sukanya.d@psu.ac.th; Tel.: +66-74-288-888; Fax: +66-74-288-891
}

check for updates

Citation: Dej-adisai, S.; Parndaeng, K.; Wattanapiromsakul, C.; Hwang, J.S

Three New Isoprenylated Flavones

from Artocarpus chama Stem and

Their Bioactivities. Molecules 2022, 27,

3. https://doi.org/10.3390/

molecules27010003

Academic Editor: Yuri Baukov

Received: 7 November 2021

Accepted: 17 December 2021

Published: 21 December 2021

Publisher's Note: MDPI stays neutral with regard to jurisdictional claims in published maps and institutional affiliations.

Copyright: (C) 2021 by the authors. Licensee MDPI, Basel, Switzerland. This article is an open access article distributed under the terms and conditions of the Creative Commons Attribution (CC BY) license (https:// creativecommons.org/licenses/by/ $4.0 /)$

\begin{abstract}
Phytochemical investigation of Artocarpus chama stem was performed by chromatographic techniques, resulting from the isolation and structure elucidation of three new compounds, namely 3'-farnesyl-apigenin (1), 3-(hydroxyprenyl) isoetin (2), and 3-prenyl-5,7,2',5'-tetrahydroxy-4' methoxyflavone (3), and five known compounds, namely homoeriodictyol (4), isocycloartobiloxanthone (5), artocarpanone (6), naringenin (7), and artocarpin (8). From the screening result, A. chama extract showed a potent tyrosinase inhibitory effect. The isolated compounds 1, 4 and 6 also exhibited tyrosinase inhibition with $\mathrm{IC}_{50}$ of $135.70,52.18$, and $38.78 \mu \mathrm{g} / \mathrm{mL}$, respectively. Moreover, compounds $\mathbf{3}, \mathbf{4}, \mathbf{5}, \mathbf{6}$, and 8 showed strong activity against Staphylococcus epidermidis, S. aureus, methicillin-resistant S. aureus, and Cutibacterium acnes. This study is the first report on phytochemical investigation with new compounds and biological activities of $A$. chama. Skin infection can cause dark spots or hyperpigmentation. The isolated compounds that showed both anityrosinase and antimicrobial activities will be further studied in in vivo and clinical trials in order to develop treatment for hyperpigmentation, which is caused by infectious diseases by microorganisms.
\end{abstract}

Keywords: Artocarpus charma; moraceae; isoprenylated flavone; antityrosinase activity; melanin content; antimicrobial activity

\section{Introduction}

Nowadays, skin whitening, or skin lightening, is popular; thus, skin-whitening agents have been searching. Melanin is an important factor that determines skin color [1]. Melanin is a polyphenolic pigment and causes dark-colored skin. It is produced in the process called melanogenesis [2]. In melanogenesis, tyrosinase enzymes, an important enzyme, catalyzes L-tyrosine to L-Dopa and to $o$-Dopaquinone- $\mathrm{H}^{+}$before passing the intermediate to the final melanin [3].

Tyrosinase is one of the main enzymes in the melanogenesis process. Therefore, inhibition of tyrosinase activity can decrease melanogenesis. The most commonly used treatment for all types of hyperpigmentary disorders is topical hydroquinone. It can lead side-effect reactions, such as skin irritation, dermatitis, melanocyte demolition, ochronosis, post-inflammatory pigmentation, cytotoxicity, and skin cancer [4].

Tyrosinase inhibitors from natural product might be an alternative way to provide the compounds for antityrosinase activity because plants are a rich source of bioactive chemicals that are mostly free from harmful side effects [5]. Nowadays, interest in tyrosinase inhibitors from natural sources is increasing [6-10]. Moraceae is the most interesting plant family to study concerning antityrosinase activity because many compounds from this family showed inhibitory activity against tyrosinase enzymes [11]. Artocarous chama, which is a plant in the Moraceae family, has been reported to show antioxidant activity [12,13] and was screened for antityrosinase and antibacterial activities [11], as well as chemical constituents, mostly flavonoids and phenolic compounds [14-16]. Flavonoids play a key 
role in newly discovered natural tyrosinase inhibitors $[17,18]$. The number and location of phenolic hydroxyl groups on flavonoids significantly influences the inhibition of tyrosinase activity [19-21].

Infection by pathogenic bacteria, for example, Cutibacterium acnes, Staphylococcus epidermidis, and S. aureus, can cause acne vulgaris or acne inflammation resulting in postinflammatory hyperpigmentation [22,23]. Therefore, effective treatment of hyperpigmentation should include antimicrobial agents.

Tyrosinase inhibition is important to reduction of melanin, may be developed into new drug to treatments for hyperpigmentation [24], and could be useful in cosmetology [25]. Tyrosinase inhibitors from natural products are getting a lot of attention. This is because plant-based tyrosinase inhibitors are cost-effective and cause fewer side effects.

\section{Results}

\subsection{Structure Elucidation of Isolated Compounds}

Eight pure compounds from EtOAc extract of A. chama stem were isolated and identified by using physical properties and spectroscopic data. Then, their chemical structures were confirmed, by comparison with previous reports, as $3^{\prime}$-Farnesylapigenin (Compound 1), 3-(Hydroxyprenyl) isoetin (Compound 2), 3-Prenyl-5,7, $2^{\prime}, 5^{\prime}-$ tetrahydroxy-4' methoxyflavone (Compound 3), Homoeriodictyol (Compound 4), Isocycloartobiloxanthone (Compound 5), Artocarpanone (Compound 6), Naringenin (Compound 7), and artocarpin (Compound 8) (Figure 1).

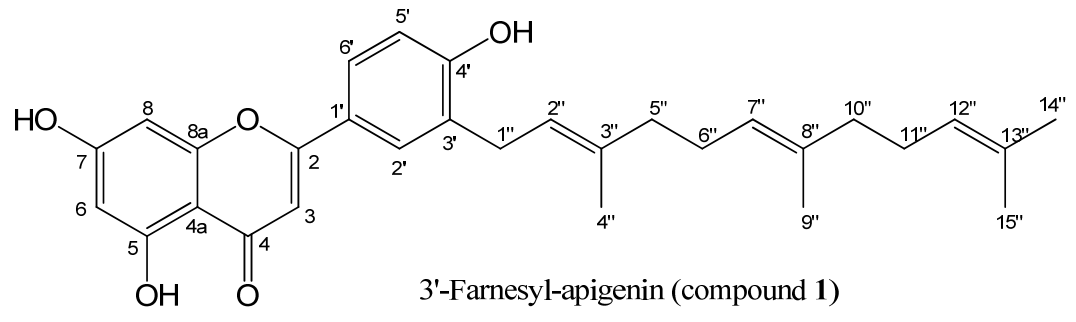<smiles>CC(C)=CC(O)c1c(-c2cc(O)c(O)cc2O)oc2cc(O)cc(O)c2c1=O</smiles>

3-(Hydroxyprenyl) isoetin (compound 2)<smiles>COc1cc(C2CC(=O)c3c(O)cc(O)cc3O2)ccc1O</smiles>

Homoeriodictyol (compound 4)<smiles>COc1cc(O)c(-c2oc3cc(O)cc(O)c3c(=O)c2CC=C(C)C)cc1O</smiles>

3-Prenyl5,7,2',5'-tetrahydroxy-4'-methoxyflavone (compound 3)<smiles>[Y][C@]1(C)Oc2c(O)cc(O)c3c2[C@@H]1Cc1c-3oc2cc3c(c(O)c2c1=O)C=C[C@@]([3H])(C)O3</smiles>

Isocycloartobiloxanthone (compound 5)

Figure 1. Cont. 
<smiles>COc1cc(O)c2c(c1)OC(c1ccc(O)cc1O)CC2=O</smiles>

Artocarpanone (compound 6)

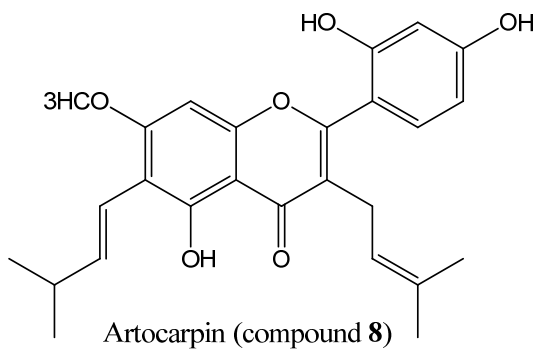<smiles>O=C1CC(c2ccc(O)cc2)Oc2cc(O)cc(O)c21</smiles>

Naringenin (compound 7)<smiles>O=c1cc(-c2ccc(O)cc2)oc2cc(O)cc(O)c12</smiles>

Figure 1. The isolated compounds and apigenin.

\subsubsection{3'-Farnesyl Apigenin; (Compound 1)}

Compound 1 was obtained as a yellow, amorphous powder, soluble in methanol. The UV spectrum in chloroform demonstrated an absorption maximum at $\lambda_{\max } 228,242,286$, and $396 \mathrm{~nm}$. The IR spectrum exhibited maximum absorption bands at 3401, 2923, 2851, and $1622 \mathrm{~cm}^{-1}$. The HR-EIMS, which showed a molecular ion peak at $m / z 497.2298$ calcd., confirmed a molecular formula of $\mathrm{C}_{30} \mathrm{H}_{34} \mathrm{O}_{5}, 497.2298$. The ${ }^{1} \mathrm{H}-\mathrm{NMR}$ spectrum exhibited three olefinic proton signals of typical ortho and meta-coupled patterns of ring $\mathrm{B}$ at $\delta_{\mathrm{H}}$ $6.87\left(1 \mathrm{H}, \mathrm{d}, J=8.2 \mathrm{~Hz}, \mathrm{H}-5^{\prime}\right), 7.68\left(1 \mathrm{H}, \mathrm{dd}, J=8.2,2.4 \mathrm{~Hz}, \mathrm{H}-6^{\prime}\right)$, and $7.63(1 \mathrm{H}, \mathrm{d}, J=2.4 \mathrm{~Hz}$, H-2' ${ }^{\prime}$. Two olefinic proton signals of a typical meta-coupled pattern due to a $1,2,3,5-$ tetrasubstituted benzene ring $\mathrm{A}$ at $\delta_{\mathrm{H}} 6.18(1 \mathrm{H}, \mathrm{d}, J=2.2 \mathrm{~Hz}, \mathrm{H}-6)$ and $6.39(1 \mathrm{H}, \mathrm{d}, J=2.1 \mathrm{~Hz}$, $\mathrm{H}-8)$. The olefinic proton signal at $\delta_{\mathrm{H}} 6.49(1 \mathrm{H}, \mathrm{s}, \mathrm{H}-3)$ indicates the characteristic of flavonering $C$ structure. The farnesyl moiety proton signals: three olefinic protons at $\delta_{\mathrm{H}} 5.34(1 \mathrm{H}$, $\left.\mathrm{td}, J=7.3,1.2 \mathrm{~Hz}, \mathrm{H}-2^{\prime \prime}\right), 5.10\left(1 \mathrm{H}, \mathrm{td}, J=7.0,1.2 \mathrm{~Hz}, \mathrm{H}-7^{\prime \prime}\right)$, and $4.94(1 \mathrm{H}, \mathrm{dd}, J=7.0,1.4 \mathrm{~Hz}$, $\left.\mathrm{H}-12^{\prime \prime}\right)$; five methylenes at $\delta_{\mathrm{H}} 3.35\left(2 \mathrm{H}, \mathrm{d}, J=7.3 \mathrm{~Hz}, \mathrm{H}-1^{\prime \prime}\right), 2.14(2 \mathrm{H}, \mathrm{dd}, J=28.7,6.5 \mathrm{~Hz}$, ${\mathrm{H}-6^{\prime \prime}}^{\prime \prime}, 2.08\left(2 \mathrm{H}, \mathrm{dd}, J=28.5,6.5 \mathrm{~Hz}, \mathrm{H}-5^{\prime \prime}\right), 1.92\left(2 \mathrm{H}, \mathrm{dd}, J=33.4,7.0 \mathrm{~Hz}, \mathrm{H}-11^{\prime \prime}\right)$, and 1.85 $\left(2 \mathrm{H}, \mathrm{dd}, J=32.7,7.0 \mathrm{~Hz}, \mathrm{H}-10^{\prime \prime}\right)$; and four methyls at $\delta_{\mathrm{H}} 1.73\left(3 \mathrm{H}, \mathrm{d}, J=1.3 \mathrm{~Hz}, \mathrm{H}-4^{\prime \prime}\right)$, $1.56\left(3 \mathrm{H}, \mathrm{d}, J=1.4 \mathrm{~Hz}, \mathrm{H}-14^{\prime \prime}\right), 1.54\left(3 \mathrm{H}, \mathrm{d}, J=1.3 \mathrm{~Hz}, \mathrm{H}-9^{\prime \prime}\right)$, and $1.48(3 \mathrm{H}, \mathrm{d}, J=1.3 \mathrm{~Hz}$, $\left.\mathrm{H}-15^{\prime \prime}\right)$. The abovementioned evidence suggests that compound $\mathbf{1}$ is a trihydroxyflavone compound with a farnesyl group. The ${ }^{13} \mathrm{C}-\mathrm{NMR}$ spectrum showed 30 carbon signals. The trihydroxyflavone moiety showed: one conjugated ketone signal at $\delta_{C} 183.83(\mathrm{C}-4)$, five oxygenated olefinic quaternary signals at $\delta_{C} 166.57(\mathrm{C}-2), 165.93$ (C-7), $163.19(\mathrm{C}-5)$, $159.39(\mathrm{C}-8 \mathrm{a})$, and $160.50\left(\mathrm{C}-4^{\prime}\right)$; three olefinic quaternary signals at $\delta_{\mathrm{C}} 130.37\left(\mathrm{C}-3^{\prime}\right), 123.10$ $\left(\mathrm{C}-1^{\prime}\right)$, and $105.33(\mathrm{C}-4 \mathrm{a})$; and six olefinic methine signals at $\delta_{\mathrm{C}} 128.92\left(\mathrm{C}-2^{\prime}\right), 126.86\left(\mathrm{C}-6^{\prime}\right)$, 116.25 (C-5'), 103.68 (C-3), 100.10 (C-6), and 95.05 (C-8). In addition, the following signals of a farnesyl moiety, confirmed with previous report [26], were observed: three olefinic quaternary signals at $\delta_{\mathrm{C}} 137.44\left(\mathrm{C}-3^{\prime \prime}\right), 136.15\left(\mathrm{C}-8^{\prime \prime}\right)$, and $131.96\left(\mathrm{C}-13^{\prime \prime}\right)$; two olefinic methines at $\delta_{C} 125.40\left(\mathrm{C}-12^{\prime \prime}\right), 125.14\left(\mathrm{C}-7^{\prime \prime}\right)$, and $123.48\left(\mathrm{C}-2^{\prime \prime}\right)$; five methylenes at $\delta_{\mathrm{C}}$ $40.80\left(\mathrm{C}-10^{\prime \prime}\right), 40.72\left(\mathrm{C}-5^{\prime \prime}\right), 28.93\left(\mathrm{C}-1^{\prime \prime}\right), 27.77\left(\mathrm{C}-11^{\prime \prime}\right)$, and $27.37\left(\mathrm{C}-6^{\prime \prime}\right)$; and four methyls at $\delta_{C} 25.81\left(C-14^{\prime \prime}\right), 17.66\left(C-15^{\prime \prime}\right), 16.26\left(C-4^{\prime \prime}\right)$, and $16.16\left(C-9^{\prime \prime}\right)$. The flavone structure and the location of the farnesyl group were proven by HMBC NMR experiments. The HMBC experiment suggested the substitution of the farnesyl moiety could be formed at the $C-3^{\prime}$ of ring $B$, which was confirmed by the key correlations in the HMBC spectrum (Figure 2). Therefore, the structure of compound 1 was elucidated as $3^{\prime}$-farnesyl apigenin, a new compound. 


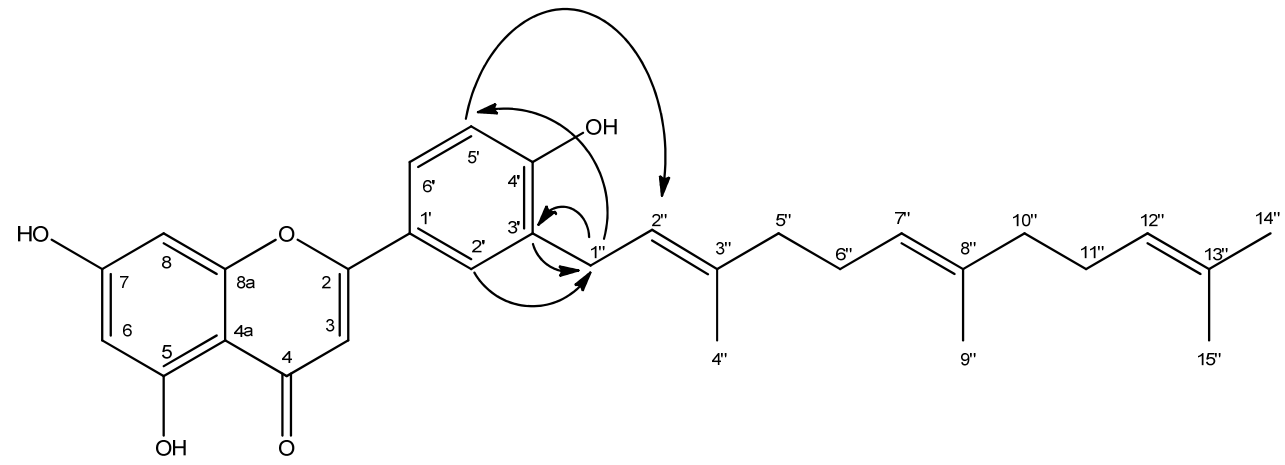

Figure 2. HMBC correlations (from $\mathrm{H}$ to $\mathrm{C}$ ) of compound 1.

\subsubsection{3-(Hydroxyprenyl) Isoetin; (Compound 2)}

Compound 2 was obtained as a yellow, amorphous powder, soluble in methanol. The UV spectrum in methanol demonstrated a maximum absorption at $\lambda_{\max } 237,275$, and $292 \mathrm{~nm}$. The IR spectrum exhibited maximum absorption bands at 3435, 1652, and $1550 \mathrm{~cm}^{-1}$. The ESIMS showed an $[\mathrm{M}+\mathrm{Na}]^{+}$ion peak at $m / z 409.1618$, correlated with a molecular formula of $\mathrm{C}_{20} \mathrm{H}_{18} \mathrm{O}_{8}$. In the ${ }^{1} \mathrm{H}-\mathrm{NMR}$ spectrum, two olefinic signals at $\delta_{\mathrm{H}} 7.13$ $\left(1 \mathrm{H}, \mathrm{s}, \mathrm{H}-6^{\prime}\right)$ and $6.33\left(1 \mathrm{H}, \mathrm{s}, \mathrm{H}-3^{\prime}\right)$, owing to a tetrasubstituted benzene ring, $\mathrm{B}$, and two olefinic signals of a typical meta-coupled pattern at $\delta_{\mathrm{H}} 6.37(1 \mathrm{H}, \mathrm{d}, J=1.7 \mathrm{~Hz}, \mathrm{H}-8)$ and 6.16 $(1 \mathrm{H}, \mathrm{d}, J=1.9, \mathrm{~Hz}, \mathrm{H}-6)$, due to a 1,2,3,5-tetrasubstituted benzene ring, A, were observed. In addition, hydroxyprenyl moiety proton signals of two methines at $\delta_{\mathrm{H}} 6.09(1 \mathrm{H}, \mathrm{d}, J=9.2 \mathrm{~Hz}$, $\mathrm{H}-9)$ and $5.42(1 \mathrm{H}, \mathrm{dt}, J=9.2,1.2 \mathrm{~Hz}, \mathrm{H}-10)$ were observed. The abovementioned evidence suggests that compound 2 is a pentahydroxyflavone compound with a hydroxyprenyl group. The oxygenated carbon signals at $\delta_{C} 70.21$ indicate a hydroxyl group of the side chain, hydroxyprenyl. The flavone structure and the location of hydroxyprenyl moiety at C-3 were confirmed based on the HMBC experiments (Figure 3). Thus, the structure of compound 2 was determined to be 3-(hydroxyprenyl) isoetin, a new compound.

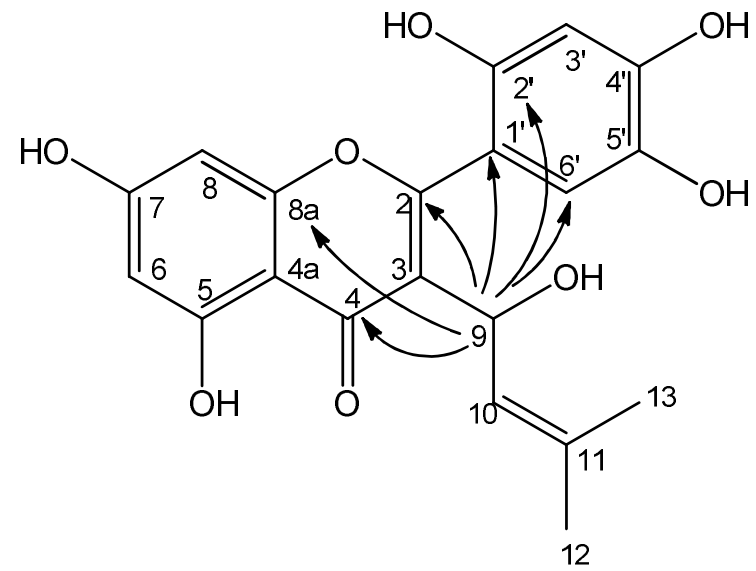

Figure 3. HMBC correlations (from $\mathrm{H}$ to $\mathrm{C}$ ) of compound 2.

\subsubsection{3-Prenyl-5,7,2', 5' -Tetrahydroxy-4'-Methoxyflavone; (Compound 3)}

Compound 3 was obtained as a yellow, amorphous powder, soluble in methanol. The UV spectrum in methanol demonstrated a maximum absorption at $\lambda_{\max } 205,253$, and $331 \mathrm{~nm}$. The IR spectrum exhibited maximum absorption bands at 3412, 1652, 1615, $1512,1448,1430,1359,1297$, and $1166 \mathrm{~cm}^{-1}$. The HR-ESIMS showed an $[\mathrm{M}+\mathrm{Na}]^{+}$ion peak at $m / z 407.1101$, correlated with a molecular formula of $\mathrm{C}_{21} \mathrm{H}_{20} \mathrm{O}_{7}$. The ${ }^{1} \mathrm{H}-\mathrm{NMR}$ and ${ }^{13} \mathrm{C}$-NMR data of compound 3 were quite similar to those of compound 2, except for the replacement of the methylene signal at $\delta_{\mathrm{H}} 3.01(2 \mathrm{H}, \mathrm{d}, J=7.0 \mathrm{~Hz}, \mathrm{H}-9)$ and the methoxyl signal at $\delta_{\mathrm{H}} 3.71\left(3 \mathrm{H}, \mathrm{s}, 4^{\prime}-\mathrm{OCH}_{3}\right)$ of ring $\mathrm{B}$. The carbon signals of compound 3 
were in agreement with those of compound 2, except that the carbon signal at position C-9 (24.85) was shifted up field by $45.36 \mathrm{ppm}$, compared with the carbon chemical shift of compound 2 (70.21), due to oxygenation effects, indicating a methylene group at C-9. Moreover, the signals of the B ring suggested that the methoxy group in compound 3 was possibly presented in the B ring. These findings indicated that compound 3 is was a tetrahydroxyflavone compound with a prenyl group. The flavone structure and the location of the prenyl moiety were confirmed based on the HMBC experiment (Figure 4). Thus, the structure of compound 3 was determined to be 3-prenyl-5,7,2',5'-tetrahydroxy$4^{\prime}$ - methoxyflavone, a new prenylated flavone.

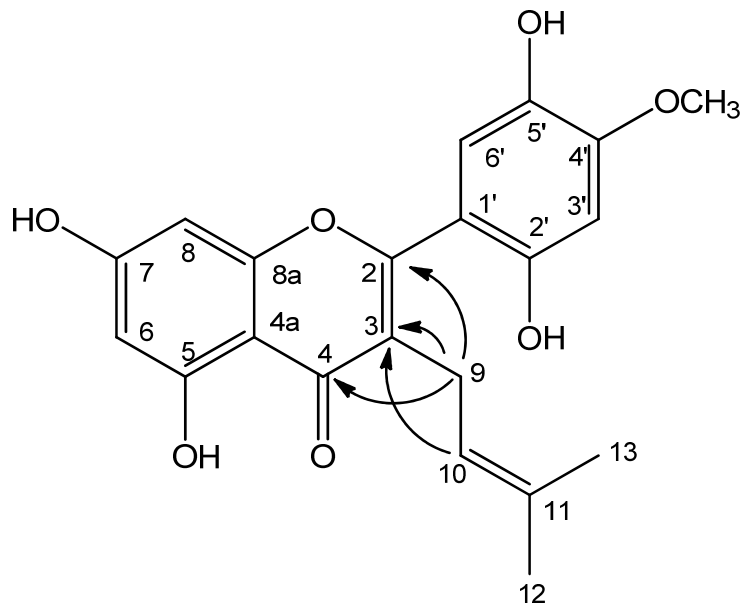

Figure 4. HMBC correlations (from $\mathrm{H}$ to $\mathrm{C}$ ) of compound 3.

\subsection{Enzymatic Antityrosinase Activity}

Tyrosinase inhibitory activity of the isolated compounds from A. chama was determined by the dopachrome method. Artocarpanone (Compound 6), showed the highest activity against tyrosinase enzymes, with $\mathrm{IC}_{50}$ of $38.78 \mu \mathrm{g} / \mathrm{mL}$, followed by homoeriodictyol (Compound 4), with $\mathrm{IC}_{50}$ of $52.18 \mu \mathrm{g} / \mathrm{mL}$, while, $3^{\prime}$-farnesyl-apigenin (Compound 1), exhibited the moderate tyrosinase inhibitory activity, with $\mathrm{IC}_{50}$ of $135.70 \mu \mathrm{g} / \mathrm{mL}$. Five isolated compounds showed $\mathrm{IC}_{50}$ of higher than $200 \mu \mathrm{g} / \mathrm{mL}$ : isocycloartobiloxanthone (Compound 5), 3-(hydroxyprenyl) isoetin (Compound 2), 3-prenyl-5,7,2',5'-tetrahydroxy-4' methoxyflavone (Compound 3), naringenin (Compound 7), and artocarpin (Compound 8). The results are presented in Table 1.

Table 1. $\mathrm{IC}_{50}$ of isolated compounds from A. chama on tyrosinase inhibitory activity.

\begin{tabular}{|c|c|c|}
\hline Compound & & $\mathrm{IC}_{50}(\mu \mathrm{g} / \mathrm{mL})$ \\
\hline 1 & 3'-farnesyl-apigenin & $135.70 \pm 1.16$ \\
\hline 2 & 3-(hydroxyprenyl) isoetin & $>200$ \\
\hline 3 & 3-prenyl-5,7, $2^{\prime}, 5^{\prime}$-tetrahydroxy-4'-methoxyflavone & $>200$ \\
\hline 4 & homoeriodictyol & $52.18 \pm 0.95$ \\
\hline 5 & isocycloartobiloxanthone & $>200$ \\
\hline 6 & artocarpanone & $38.78 \pm 1.02$ \\
\hline 7 & naringenin & $>200$ \\
\hline 8 & artocarpin & $>200$ \\
\hline Std. & Kojic acid ${ }^{\mathrm{P}}$ & $38.67 \pm 0.94$ \\
\hline Std. & Water extract of $A$. lakoocha wood ${ }^{\mathrm{P}}$ & $8.73 \pm 0.69$ \\
\hline
\end{tabular}

$\mathrm{P}$ for positive standards.

\subsection{Cell Viability}

The initial purpose was to test whether the isolated compounds could inhibit melanogenesis in cultured melanocytes without affecting cell growth. The results showed that 
all the isolated compounds were not toxic to B16-F1 melanoma cells. Cell viability was still more than $80 \%$ at the highest concentration of $50 \mu \mathrm{g} / \mathrm{mL}$. The results are presented in Figure 5.

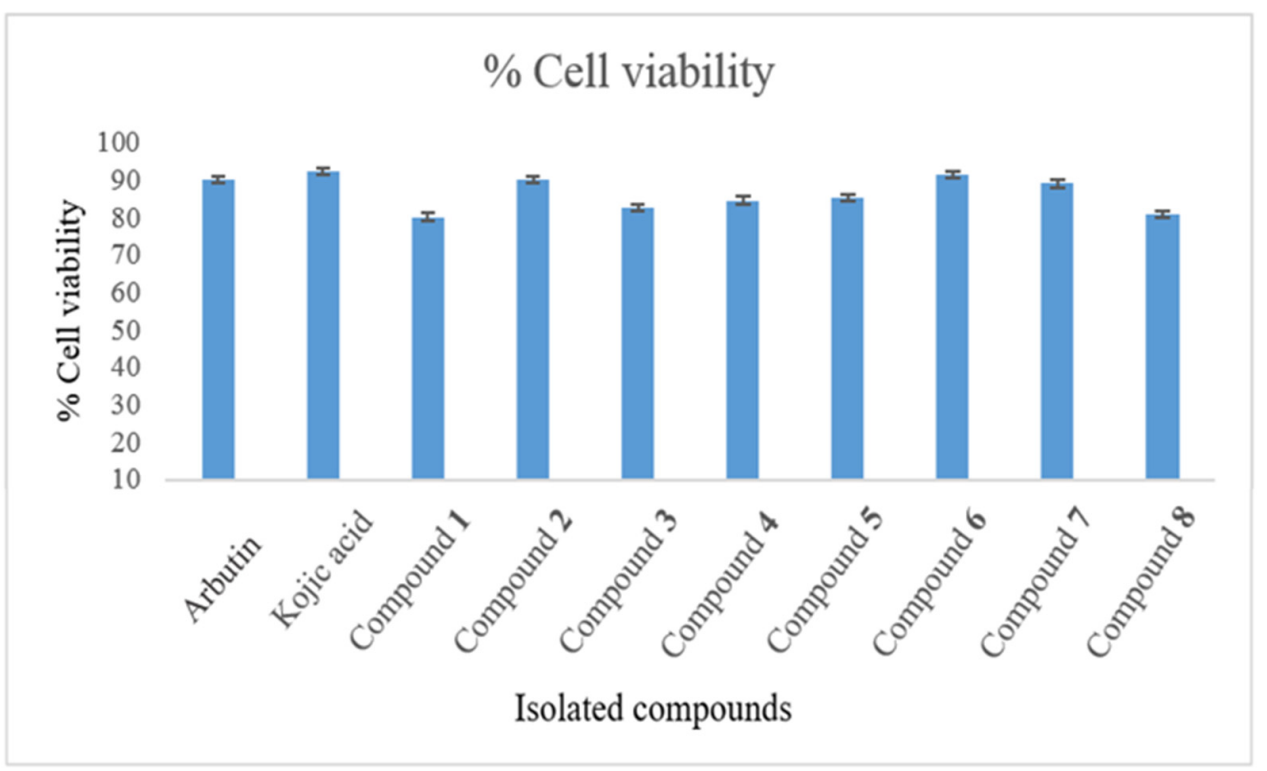

Figure 5. Cell viability of isolated compounds at a concentration $50 \mu \mathrm{g} / \mathrm{mL}$.

\subsection{Intracellular Antityrosinase Activity and Melanin Content}

The effects of the isolated compounds at concentrations of $50 \mu \mathrm{g} / \mathrm{mL}$ on intracellular antityrosinase activity and melanin content of B16F1 melanoma cells was determined. The antityrosinase activity of supernatants was measured, and the results showed that Compound 6 (artocarpanone) exhibited antityrosinase activity (Figure 6A). Moreover, melanin content showed an inverse result with antityrosinase activity; usually the increase of antityrosinase activity led to the decrease of melanin content (Figure 6B).

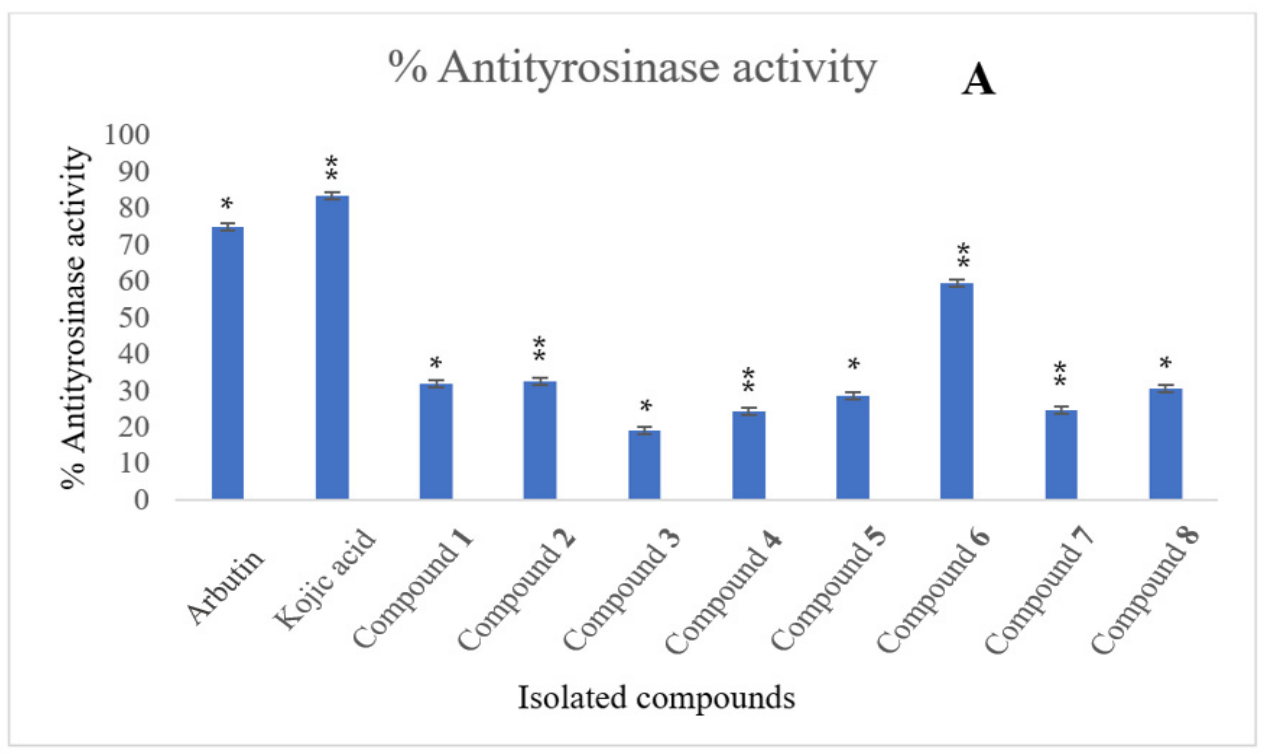

Figure 6. Cont. 


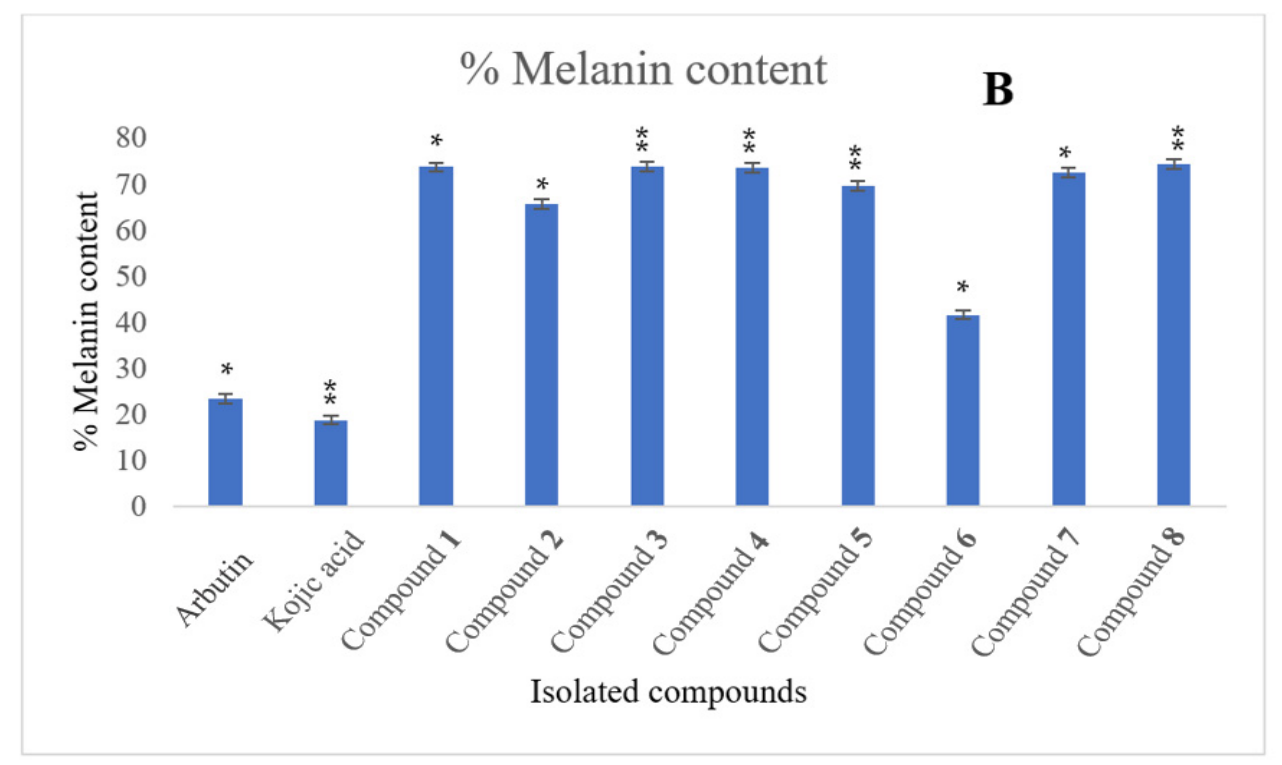

Figure 6. Intracellular antityrosinase activity (A) and melanin content (B). Data were expressed as mean \pm SD from three independent experiments. ${ }^{*} p<0.05$, and ${ }^{* *} p<0.01$ indicated a significant difference from the positive control group. Positive controls were arbutin and kojic acid.

\subsection{Antimicrobial Activity Assay}

From the screening of antimicrobial activity [11], ethyl acetate extracts of A. chama and S. taxoides showed potential effects against S. epidermidis, S. aureus, MRSA, and P. acnes. Thus, the ethyl acetate extracts of these plants were selected for further isolation of active compounds. Then, the MIC and MBC of isolated compounds were investigated for $S$. epidermidis, S. aureus, MRSA, and C. acnes. The MIC and MBC values of the isolated compounds are presented in Table 2.

Table 2. MIC and MBC of isolated compounds against S. epidermidis, S. aureus, MRSA, and C. acnes.

\begin{tabular}{|c|c|c|c|c|c|c|c|c|}
\hline \multirow[b]{2}{*}{ Compounds } & \multicolumn{2}{|c|}{ S. epidermidis } & \multicolumn{2}{|c|}{ S. aureus } & \multicolumn{2}{|c|}{ MRSA } & \multicolumn{2}{|c|}{ C. acnes } \\
\hline & $\begin{array}{c}\text { MIC } \\
(\mu \mathrm{g} / \mathrm{mL})\end{array}$ & $\begin{array}{c}\text { MBC } \\
(\mu \mathrm{g} / \mathrm{mL})\end{array}$ & $\begin{array}{c}\text { MIC } \\
(\mu \mathrm{g} / \mathrm{mL})\end{array}$ & $\begin{array}{c}\text { MBC } \\
(\mu \mathrm{g} / \mathrm{mL})\end{array}$ & $\begin{array}{c}\text { MIC } \\
(\mu \mathrm{g} / \mathrm{mL})\end{array}$ & $\begin{array}{c}\text { MBC } \\
(\mu \mathrm{g} / \mathrm{mL})\end{array}$ & $\begin{array}{c}\text { MIC } \\
(\mu \mathrm{g} / \mathrm{mL})\end{array}$ & $\begin{array}{c}\text { MBC } \\
(\mu \mathrm{g} / \mathrm{mL})\end{array}$ \\
\hline 1 & 256 & $>256$ & 256 & $>256$ & $>256$ & $>256$ & $>256$ & $>256$ \\
\hline 2 & 16 & 32 & 16 & 32 & 16 & 64 & 128 & $>256$ \\
\hline 3 & 16 & 64 & 4 & 16 & 4 & 32 & 128 & $>256$ \\
\hline 4 & 128 & 256 & 256 & $>256$ & $>256$ & $>256$ & $>256$ & $>256$ \\
\hline 5 & 4 & 8 & 4 & 8 & 16 & 64 & 256 & $>256$ \\
\hline 6 & 64 & 128 & 64 & 256 & 128 & $>256$ & 32 & 64 \\
\hline 7 & 256 & $>256$ & $>256$ & $>256$ & $>256$ & $>256$ & $>256$ & $>256$ \\
\hline 8 & 2 & 32 & 2 & 4 & 2 & 2 & 8 & 32 \\
\hline Oxa ${ }^{\mathrm{P}}$ & 0.5 & 0.5 & 0.125 & 0.125 & NT & NT & 0.5 & 0.5 \\
\hline $\operatorname{Van}^{P}$ & NT & NT & NT & NT & 0.125 & 0.5 & NT & NT \\
\hline
\end{tabular}

${ }^{\mathrm{P}}$ for positive controls; Oxa = Oxacillin; Van = Vancomycin.

\section{Discussion}

All isolated compounds (Figure 1) were in the flavonoid group and can be divided in two sub-groups. The group first is flavanones, composed of homoeriodictyol, artocarpanone, and naringenin, while the second group is flavones, composed of $3^{\prime}$-farnesylapigenin, 3-(hydroxylprenyl) isoetin, 3-prenyl-5,7,2', 5' -tetrahydroxy-4'-methoxyflavone, isocycloartobiloxanthone, and artocarpin. Homoeriodictyol, artocarpanone, and $3^{\prime}$-farnesylapigenin showed direct activity against tyrosinase enzymes. The related 4-substituted resorcinols suggest that compounds with the 4-substituted resorcinol skeletons exhibit 
potent tyrosinase inhibitory activity [27]. The additional group, a farnesyl group at position C- $3^{\prime}$ was not affected to tyrosinase activity when compared with the activity of apigenin (without farnesyl at position C-3') [28], while the substitution at position C-3 was critical for the tyrosinase inhibitory activity of the flavone group [29]. Thus, 3-(hydroxyprenyl) isoetin, 3-prenyl-5,7, 2', $5^{\prime}$-tetrahydroxy-4'-methoxyflavone, and artocarpin, which were substituted with prenyl, as well as isocycloartobiloxanthone, which was substituted with cyclohexane at position C-3, did not exhibit antityrosinase activity.

However, only artocarpanone could reduce the amount of melanin content and exhibited intracellular antityrosinase activity on B16F1 melanoma cells. This could be due to melanogenesis processes, such as microphthalmia-associated transcription factor (MITF), because melanogenesis-related enzyme expression can activate or depress by up or down regulation of MITF activity; therefore it could exhibit a stimulatory or inhibitory effect on melanogenesis [30-32].

3-(Hydroxyprenyl) isoetin, 3-prenyl-5,7,2', $5^{\prime}$-tetrahydroxy-4'-methoxyflavone, isocycloartobiloxanthone, artocarpanone, and artocarpin exhibited potential antibacterial activity against Gram-positive bacteria (S. epidermidis, S. aureus, MRSA and C. acnes), owing to the substituents and positions of hydroxyl and isoprenyl groups. The saturation of the $\mathrm{C} 2=\mathrm{C} 3$ double bond and the presence of hydroxyl groups at C-5, C-6, or C-7 (especially at C-5 and C-7) of the A ring [33,34], as well as another position, such as C-2' or \#\#\# The meaning is fine, just correcting some words.C- $4^{\prime}$ of the $\mathrm{B}$ ring, could improve the antibacterial effect [35]. Moreover, an increase of hydrophobicity by prenylation could enhance antibacterial activity, especially in substituents with isoprenyl groups at C-6 or C-8 [35]. Furthermore, diprenylated substituents wer more effective against the Gram-positive bacteria than monoprenylated substituents [33].

\section{Experimantal Section}

\subsection{Plant Materials}

Stems of Artocarpus chama Buch. Was collected from Southern Literature Botanical Garden, Songkhla Province. The plant was identified by a botanist of Southern Literature Botanical Garden, and the voucher specimen number was SKP 1170103 01. The sample specimen was kept at the Department of Pharmacognosy and Pharmaceutical Botany, Faculty of Pharmaceutical Sciences, Prince of Songkla University, Thailand.

\subsection{Extraction and Isolation}

$6.8 \mathrm{~kg}$ of A. chama stem powder was macerated repeatedly with petroleum ether for 3 days ( 3 times). Then, the extraction was filtrated, and the solvent was evaporated using a rotary evaporator under reduced pressure at $40{ }^{\circ} \mathrm{C}$ to yield a petroleum ether extract. Then, the marc was macerated three times with ethyl acetate and methanol for 3 days ( 3 times each) and boiled with $\mathrm{H}_{2} \mathrm{O}$. Next, the solvent was removed to provide ethyl acetate, methanol, and $\mathrm{H}_{2} \mathrm{O}$ extracts.

Based on screening results, the ethyl acetate extract showed potent effects on antityrosinase and antimicrobial activities. Therefore, it was selected for further phytochemical investigation. First, the ethyl acetate extract $(40 \mathrm{~g})$ was fractionated by quick-column chromatography, and the eluates were examined by TLC using a gradient solvent system between hexane, ethyl acetate, and methanol. The fractions that showed the similar TLC fingerprints were combined. The interesting fractions, D, F, G and H, were selected to isolate and purify. The isolation step is illustrated in Scheme 1. Afterward, the chemical structures of the isolated compounds were interpreted using nuclear magnetic resonance (NMR) and other spectroscopic techniques. 


\section{$40 \mathrm{~g}$ of EtOAc extract from $A$. chama stem}

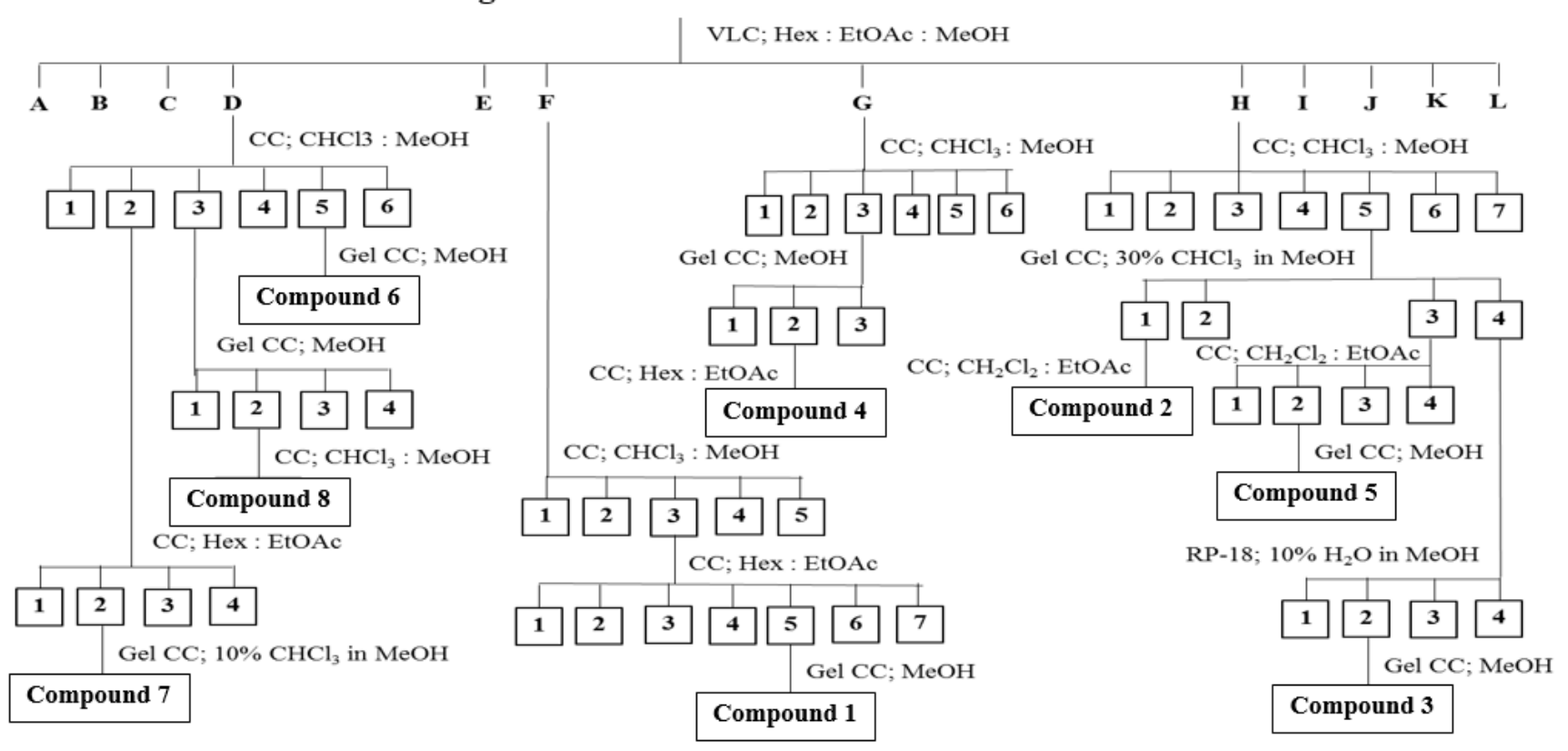

Scheme 1. Phytochemical investigation of ethyl acetate extract (EtOAc) from A. chama stem. VLC, vacuum liquid chromatography; $\mathrm{CC}$, classical column chromatography; gel CC, Sephadex ${ }^{\circledR}$ LH-20; FA, formic acid; Hex, Hexane; $\mathrm{CH}_{2} \mathrm{Cl}_{2}$, dichloromethane; $\mathrm{CHCl}_{3}$, chloroform; EtOAc, ethyl acetate; $\mathrm{MeOH}$, methanol; $\mathrm{H}_{2} \mathrm{O}$, water.

\subsection{Spectroscopic Data}

\subsubsection{3'-Farnesyl Apigenin; $\mathrm{C}_{30} \mathrm{H}_{34} \mathrm{O}_{5}$ (Compound 1)}

${ }^{1} \mathrm{H}-\mathrm{NMR}\left(500 \mathrm{MHz}, \mathrm{CD}_{3} \mathrm{OD}\right): 7.63\left(1 \mathrm{H}, \mathrm{d}, J=2.4 \mathrm{~Hz}, \mathrm{H}-2^{\prime}\right), 7.62(1 \mathrm{H}, \mathrm{dd}, J=8.2,2.4 \mathrm{~Hz}$, $\left.\mathrm{H}^{\prime} 6^{\prime}\right), 6.87\left(1 \mathrm{H}, \mathrm{d}, J=8.2 \mathrm{~Hz}, \mathrm{H}-5^{\prime}\right), 6.49(1 \mathrm{H}, \mathrm{s}, \mathrm{H}-3), 6.39(1 \mathrm{H}, \mathrm{d}, J=2.1 \mathrm{~Hz}, \mathrm{H}-8), 6.18(1 \mathrm{H}$, $\mathrm{d}, J=2.2 \mathrm{~Hz}, \mathrm{H}-6), 5.34\left(1 \mathrm{H}, \mathrm{td}, J=7.3,1.2 \mathrm{~Hz}, \mathrm{H}-2^{\prime \prime}\right), 5.10\left(1 \mathrm{H}, \mathrm{td}, J=7.0,1.2 \mathrm{~Hz}, \mathrm{H}-7^{\prime \prime}\right), 4.94$ $\left(1 \mathrm{H}, \mathrm{tt}, J=7.0,1.4 \mathrm{~Hz}, \mathrm{H}-12^{\prime \prime}\right), 3.35\left(2 \mathrm{H}, \mathrm{d}, J=7.3 \mathrm{~Hz}, \mathrm{H}-1^{\prime \prime}\right), 2.14(2 \mathrm{H}, \mathrm{dd}, J=28.7,6.5 \mathrm{~Hz}$, ${\mathrm{H}-6^{\prime \prime}}^{\prime \prime}, 2.08\left(2 \mathrm{H}, \mathrm{dd}, J=28.5,6.5 \mathrm{~Hz}, \mathrm{H}-5^{\prime \prime}\right), 1.92\left(2 \mathrm{H}, \mathrm{dd}, J=33.4,7.0 \mathrm{~Hz}, \mathrm{H}-11^{\prime \prime}\right), 1.85(2 \mathrm{H}$, $\left.\mathrm{dd}, J=32.7,7.0 \mathrm{~Hz}, \mathrm{H}-10^{\prime \prime}\right), 1.73\left(3 \mathrm{H}, \mathrm{d}, J=1.3 \mathrm{~Hz}, \mathrm{H}-4^{\prime \prime}\right), 1.56\left(3 \mathrm{H}, \mathrm{d}, J=1.4 \mathrm{~Hz}, \mathrm{H}-14^{\prime \prime}\right)$, $1.54\left(3 \mathrm{H}, \mathrm{d}, J=1.3 \mathrm{~Hz}, \mathrm{H}-9^{\prime \prime}\right)$ and $1.48\left(3 \mathrm{H}, \mathrm{d}, J=1.3 \mathrm{~Hz}, \mathrm{H}-15^{\prime \prime}\right)$.

${ }^{13} \mathrm{C}-\mathrm{NMR}\left(125 \mathrm{MHz}, \mathrm{CD}_{3} \mathrm{OD}\right): 183.83$ (C-4), 166.57 (C-2), 165.93 (C-7), 163.19 (C-5), $160.50\left(\mathrm{C}-4^{\prime}\right), 159.39(\mathrm{C}-8 \mathrm{a}), 137.44\left(\mathrm{C}-3^{\prime \prime}\right), 136.15\left(\mathrm{C}-8^{\prime \prime}\right), 131.96\left(\mathrm{C}-13^{\prime \prime}\right), 130.37\left(\mathrm{C}-3^{\prime}\right), 128.92$ $\left(\mathrm{C}-2^{\prime}\right), 126.86\left(\mathrm{C}-6^{\prime}\right), 125.40\left(\mathrm{C}-12^{\prime \prime}\right), 125.14\left(\mathrm{C}-7^{\prime \prime}\right), 123.48\left(\mathrm{C}-2^{\prime \prime}\right), 123.10\left(\mathrm{C}-1^{\prime}\right), 116.25\left(\mathrm{C}-5^{\prime}\right)$, 105.33 (C-4a), 103.68 (C-3), 100.10 (C-6), 95.05 (C-8), $40.80\left(\mathrm{C}-10^{\prime \prime}\right), 40.72\left(\mathrm{C}-5^{\prime \prime}\right), 28.93\left(\mathrm{C}-1^{\prime \prime}\right)$, $27.77\left(\mathrm{C}-11^{\prime \prime}\right), 27.37\left(\mathrm{C}-6^{\prime \prime}\right), 25.81\left(\mathrm{C}-14^{\prime \prime}\right), 17.66\left(\mathrm{C}-15^{\prime \prime}\right), 16.26\left(\mathrm{C}-4^{\prime \prime}\right)$ and $16.16\left(\mathrm{C}-9^{\prime \prime}\right)$.

\subsubsection{3-(Hydroxyprenyl) Isoetin; $\mathrm{C}_{20} \mathrm{H}_{18} \mathrm{O}_{8}$ (Compound 2)}

${ }^{1} \mathrm{H}-\mathrm{NMR}\left(500 \mathrm{MHz}, \mathrm{CD}_{3} \mathrm{OD}\right): 7.13\left(1 \mathrm{H}, \mathrm{s}, \mathrm{H}-6^{\prime}\right), 6.37(1 \mathrm{H}, \mathrm{d}, J=1.7 \mathrm{~Hz}, \mathrm{H}-8), 6.33(1 \mathrm{H}$, s, H-3') $6.16(1 \mathrm{H}, \mathrm{d}, J=1.9, \mathrm{~Hz}, \mathrm{H}-6), 6.09(1 \mathrm{H}, \mathrm{d}, J=9.2 \mathrm{~Hz}, \mathrm{H}-9), 5.42(1 \mathrm{H}, \mathrm{dt}, J=9.2$, $1.2 \mathrm{~Hz}, \mathrm{H}-10), 1.92(3 \mathrm{H}, \mathrm{d}, J=1.2 \mathrm{~Hz}, \mathrm{H}-13)$ and $1.68(3 \mathrm{H}, \mathrm{d}, J=0.8 \mathrm{~Hz}, \mathrm{H}-12)$.

${ }^{13} \mathrm{C}-\mathrm{NMR}$ (125 MHz, CD $\left.\mathrm{OD}\right): 166.40$ (C-4'), 165.47 (C-7), 163.31 (C-5), 158.61 (C-8a),

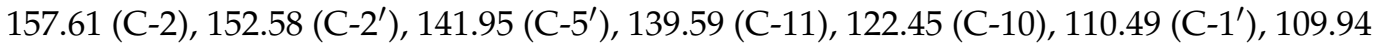
$\left(\mathrm{C}-6^{\prime}\right), 107.77(\mathrm{C}-3), 105.64\left(\mathrm{C}-3^{\prime}\right), 105.44(\mathrm{C}-4 \mathrm{a}), 99.99$ (C-6) and 95.01 (C-8), 70.21 (C-9), 25.93 (C-12) and 18.66 (C-13).

\subsubsection{3-Prenyl-5,7,2', $5^{\prime}$-tetrahydroxy-4'-methoxyflavone; $\mathrm{C}_{21} \mathrm{H}_{20} \mathrm{O}_{7}$ (Compound 3)}

${ }^{1} \mathrm{H}-\mathrm{NMR}\left(500 \mathrm{MHz}, \mathrm{CD}_{3} \mathrm{OD}\right): 6.71\left(1 \mathrm{H}, \mathrm{s}, \mathrm{H}-6^{\prime}\right), 6.59\left(1 \mathrm{H}, \mathrm{s}, \mathrm{H}-3^{\prime}\right), 6.23(1 \mathrm{H}, \mathrm{d}$, $J=2.0 \mathrm{~Hz}, \mathrm{H}-8), 6.17(1 \mathrm{H}, \mathrm{d}, J=2.0 \mathrm{~Hz}, \mathrm{H}-6), 5.05(1 \mathrm{H}, \mathrm{m}, \mathrm{H}-10), 3.71\left(3 \mathrm{H}, \mathrm{s}, 4^{\prime}-\mathrm{OCH}_{3}\right), 3.01$ $(2 \mathrm{H}, \mathrm{d}, J=7.0 \mathrm{~Hz}, \mathrm{H}-9), 1.58(3 \mathrm{H}, \mathrm{d}, J=0.5 \mathrm{~Hz}, \mathrm{H}-12)$ and $1.36(3 \mathrm{H}, \mathrm{d}, J=0.5 \mathrm{~Hz}, \mathrm{H}-13)$. 
${ }^{13} \mathrm{C}-\mathrm{NMR}\left(125 \mathrm{MHz}, \mathrm{CD}_{3} \mathrm{OD}\right): 183.53$ (C-4), 165.57 (C-7), 163.24 (C-5), 162.97 (C-2), 159.73 (C-8a), $152.53\left({\mathrm{C}-4^{\prime}}^{\prime}\right), 149.69\left(\mathrm{C}-2^{\prime}\right), 139.93$ (C-5'), 132.68 (C-11), 122.67 (C-10), 121.85

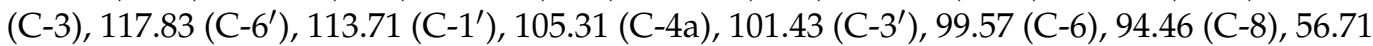
$\left(4^{\prime}-\mathrm{OCH}_{3}\right), 24.85(\mathrm{C}-9), 25.82(\mathrm{C}-12)$ and $17.56(\mathrm{C}-13)$.

The known natural products, homoeriodictyol (compound 4) [36], isocycloartobiloxanthone (compound 5) [37], artocarpanone (compound 6) [38], naringenin (compound 7) [39], and artocarpin (compound 8) [38], were identified by comparing their NMR data with previously published data.

\subsection{Enzymetic Antityrosinase Activity Assay}

Antityrosinase activity was determined by the dopachrome method. L-dopa was used as the substrate. Oxidation of L-Dopa to dopachrome which, represented by red color, could be detected by visible light at $492 \mathrm{~nm}[40,41]$. Briefly, $140 \mu \mathrm{L}$ of phosphate buffer $\mathrm{pH} 6.8,20 \mu \mathrm{L}$ of sample solution $(200 \mu \mathrm{g} / \mathrm{mL})$, and $2 \mu \mathrm{L}$ of tyrosinase enzyme solution (203.3 unit $/ \mathrm{mL}$ ) were mixed in a 96 -well plate at $25^{\circ} \mathrm{C}$ for $10 \mathrm{~min}$. Then, $20 \mu \mathrm{L}$ of L-Dopa $(0.85 \mathrm{mM})$ was added, and optical density (OD) was detected. After incubation at $25{ }^{\circ} \mathrm{C}$ for $20 \mathrm{~min}$, OD was detected again. Dimethyl sulfoxide (DMSO) was used as a negative control. Kojic acid and water extract of $A$. lakoocha wood were used as positive controls. The percent inhibition of tyrosinase reaction was calculated by the following equation:

Tyrosinase inhibition $(\%)=\left[1-\left(\mathrm{OD}_{492}\right.\right.$ of sample $/ \mathrm{OD}_{492}$ of control $\left.)\right] \times 100$.

\subsection{Cell Culture}

Murine melanoma B16-F1 cells (CLS-400122) were cultured in DMEM or Dulbecco's modified Eagle medium containing 10\% FBS heat-inactivated fetal bovine serum at $37^{\circ} \mathrm{C}$ in a humidified atmosphere with $5 \% \mathrm{CO}_{2}$. When cells reached $70-80 \%$ confluence cell viability, cellular tyrosinase activity and melanin content were measured [28,42-44].

\subsection{Cell Viability Assay}

Cell viability was determined by Sulforhodamine B (SRB) assay. First, $5 \times 10^{3}$ cells/well were seeded in a 96-well plate, incubated for $24 \mathrm{~h}$, and treated with test samples; control cells were treated with $0.5 \%$ DMSO. After $48 \mathrm{~h}$ incubation, cells were fixed with $10 \%$ trichloroacetic acid (TCA) and kept at $4{ }^{\circ} \mathrm{C}$ for $1 \mathrm{~h}$. After being strained with $0.45 \%$ SRB, $10 \mathrm{mM}$ Tris base was added and shaken to dissolve the SRB color. Optical densities were determined at $492 \mathrm{~nm}$. The percent cell viability was calculated.

\subsection{Intracellular Antityrosinase Activity and Melanin Content Assays}

First, $3 \times 10^{5}$ cells / well were seeded in 12-well plates and allowed to adhere at $37^{\circ} \mathrm{C}$ for $12 \mathrm{~h}$. Cells were treated with test samples; control cells were treated with $0.5 \%$ DMSO. After $48 \mathrm{~h}$ incubation, cells were lysed with RIPA and centrifuged at 14,000 rpm for $20 \mathrm{~min}$ $\left(4{ }^{\circ} \mathrm{C}\right)$ in order to separate the supernatant for measurement of tyrosinase activity, and the cell pellet was measured for melanin content.

\subsubsection{Intracellular Antityrosinase Activity}

The supernatant was collected for determination of protein content by the Bradford method, with bovine serum albumin (BSA) used as a standard. The supernatant of lysate cells and $2 \mathrm{mg} / \mathrm{mL}$ L-Dopa were added to a 96-well plate and incubated at $25{ }^{\circ} \mathrm{C}$ for 1 h. After that, optical densities were determined at $492 \mathrm{~nm}$. Tyrosinase inhibition was then calculated.

\subsubsection{Melanin Content}

Cell pellets were dissolved with $1 \mathrm{M} \mathrm{NaOH}$ and incubated at $55^{\circ} \mathrm{C}$ for $1 \mathrm{~h}$. Melanin content was calculated by comparison with the standard curve of synthetic melanin at $475 \mathrm{~nm}$. 


\subsection{Antimicrobial Activity Assay}

Microorganisms that cause skin infection, such as Staphylococcus aureus (ATTC 25923), Staphylococcus epidermidis (TISTR 517), Cutibacterium acnes (DMST 14916), and methicillinresistant Staphylococcus aureus (DMST20654), t were selected for this study. The isolated compounds were determined for minimum inhibitory concentration (MIC) and minimum bactericidal concentration (MBC) by a modified broth microdilution method $[45,46]$. Briefly, $20 \mu \mathrm{L}$ of the test samples (dilution series ranging from 2560 to $1.25 \mu \mathrm{g} / \mathrm{mL}$ ) was added in wells 1 to 12. Then, $80 \mu \mathrm{L}$ of media was added into each well. Next, $100 \mu \mathrm{L}$ of the inoculum (concentration $10^{6} \mathrm{CFU} / \mathrm{mL}$ ) was added in each well. The final concentration of inoculum in each well was $5 \times 10^{5} \mathrm{CFU} / \mathrm{mL}$. Then, the cultures were incubated follow the conditions. Incubation mixtures showing positive results of inhibitory effect (MIC) were streaked on media agar, and then incubated by following the conditions. The lowest concentration that did not show any growth was taken as the MBC.

\section{Conclusions}

Three new compounds (1-3) and five known compounds (4-8) were isolated from the stem of $A$. chama. The chemical structures of the isolated compounds were identified on the basis of their physical properties and spectroscopic data. Compounds 1, 4, and 6 were affected to tyrosinase inhibitory activity, while compounds 3, 4, 5, 6, and 8 showed potential effects on antimicrobial activity.

This study is the first report on antityrosinase and antimicrobial activities of $A$. chama. Additionally, three new compounds were investigated. Some isolated compounds showed effects on biological activities, which can be further studied on in vivo and in clinical trials for potential use in the treatment of hyperpigmentation and/or infectious diseases caused by microorganisms.

Author Contributions: Conceptualization and supervision, S.D.-a.; methodology, S.D.-a., K.P., C.W. and J.S.H.; investigation, K.P.; writing-original draft preparation, S.D.-a. and K.P.; writing-review and editing, S.D.-a.; co-supervision, C.W.; funding acquisition, S.D.-a. All authors have read and agreed to the published version of the manuscript.

Funding: This study was financially supported by the Plant Genetic Conservation Project under the Royal Initiative of Her Royal Highness Princess Maha Chakri Sirindhorn (RSPG project), the Prince of Songkla University (PSU) Ph.D. scholarship (PSU/95000201/2557), and Discipline of Excellence (DOE) in Pharmacy trough the Faculty of Pharmaceutical Sciences, funded by the Research and Development Office, Prince of Songkla University.

Institutional Review Board Statement: Not applicable.

Informed Consent Statement: Not applicable.

Data Availability Statement: Data sharing is not applicable.

Acknowledgments: The authors would like to thank the Department of Pharmacognosy and Pharmaceutical Botany and the Pharmaceutical Laboratory Service Center, Faculty of Pharmaceutical Sciences, Prince of Songkla University for the laboratory space and equipment.

Conflicts of Interest: We declare that there is no conflict of interest.

\section{References}

1. Jang, M.H.; Ahn, T.W. Inhibitory effects of Taraxacum mongolicum with phreatic water on melanin synthesis. Integr. Med. Res. 2015, 4, 76-93. [CrossRef]

2. Lopez-Serrano, D.; Solano, F.; Sanchez-Amat, A. Identification of an operon involved in tyrosinase activity and melanin synthesis in Marinomonas mediterranea. Gene 2004, 342, 179-187. [CrossRef] [PubMed]

3. Garcia-Molina, F.; Fenoll, L.G.; Morote, J.C.; Garcia-Ruiz, P.A.; Rodriguez-Lopez, J.N.; Garcia-Canovas, F.; Tudela, J. Opposite effects of peroxidase in the initial stages of tyrosinase-catalysed melanin biosynthesis. Int. J. Biochem. Cell Biol. 2005, 37, 1179-1196. [CrossRef] [PubMed]

4. Chiari, M.E.; Vera, D.M.A.; Palacios, S.M.; Carpinella, M.C. Tyrosinase inhibitory activity of a 6-isoprenoid-substituted flavanone isolated from Dalea elegans. Bioorg. Med. Chem. 2011, 19, 3474-3482. [CrossRef] [PubMed] 
5. Pintus, F.; Spanò, D.; Corona, A.; Medda, R. Antityrosinase activity of Euphorbia characias extracts. Peer J. 2015, 3, e1305. [CrossRef] [PubMed]

6. Corradi, I.D.F.; Souza, E.D.; Sande, D.; Takahashi, J.A. Correlation between phenolic compounds contents, antityrosinase and antioxidant activities of plant extracts. Chem. Eng. Trans. 2018, 64, 109-114.

7. Koodkaew, I.; Sukonkhajorn, P. Anti-tyrosinase and antioxidant activities of Impatiens balsamina L. Songklanakarin J. Sci. Technol. 2019, 41, 686-692.

8. Panzella, L.; Napolitano, A. Natural and bioinspired phenolic compounds as tyrosinase inhibitors for the treatment of skin hyperpigmentation: Recent advances. Cosmetics 2019, 6, 57. [CrossRef]

9. Zaidi, U.K.; Ali, A.S.; Ali, A.; Naaz, I. Natural tyrosinase inhibitors: Role of herbals in the treatment of hyperpigmentary disorders. Mini Rev. Med. Chem. 2019, 19, 796-808. [CrossRef]

10. Ashooriha, M.; Khoshneviszadeh, M.; Khoshneviszadeh, M.; Rafiei, A.; Kardan, M.; Yazdian-Robati, R.; Emami, S. Kojic acid-natural product conjugates as mushroom tyrosinase inhibitors. Eur. J. Med. Chem. 2020, 201, 112480. [CrossRef] [PubMed]

11. Dej-adisai, S.; Parndaeng, K.; Wattanapiromsakul, C.; Nuankaew, W.; Kang, T.H. Effects of selected moraceae plants on tyrosinase enzyme and melanin content. Pharmacogn. Mag. 2019, 15, 708-714. [CrossRef]

12. Ahmed, T.; Uddin, M.N.; Ahmed, S.F.; Saha, A.; Farhana, K.; Rana, M.S. In vitro evaluation of antioxidant potential of Artocarpus chama Buch. fruits. J. Appl. Pharm. Sci. 2012, 2, 75-80. [CrossRef]

13. Ahmed, T.; Uddin, M.N.; Hossain, M.K.; Hasan, N.; Rana, M.S. Evaluation of antioxidant and cytotoxic potential of Artocarpus Chama Buch. seed using in vitro models. Int. J. Pharm. Pharm. 2013, 5, 283-289.

14. Wang, Y.H.; Hou, A.J.; Chen, L.; Chen, D.F.; Sun, H.D.; Zhao, Q.S.; Bastow, K.F.; Nakanish, Y.; Wang, X.H.; Lee, K.H. New isoprenylated flavones, artochamins A-E, and cytotoxic principles from Artocarpus chama. J. Nat. Prod. 2004, 67, 757-761. [CrossRef] [PubMed]

15. Wang, K.H.; Lin, R.D.; Hsu, F.L.; Huang, Y.H.; Chang, H.C.; Huang, C.Y.; Lee, M.H. Cosmetic applications of selected traditional Chinese herbal medicines. J. Ethnopharmacol. 2006, 106, 353-359. [CrossRef]

16. Wang, Y.H.; Hou, A.J.; Chen, D.F. Two new isoprenylated stilbenes from Artocarpus chama. J. Integr. Plant. Biol. 2007, 49, 605-608. [CrossRef]

17. Lee, S.Y.; Baek, N.; Nam, T.-G. Natural, semisynthetic and synthetic tyrosinase inhibitors. J. Enzym. Inhib. Med. Chem. 2016, 31, 1-13. [CrossRef]

18. Zuo, A.R.; Dong, H.H.; Yu, Y.Y.; Shu, Q.-L.; Zheng, L.-X.; Yu, X.-Y.; Cao, S.W. The antityrosinase and antioxidant activities of flavonoids dominated by the number and location of phenolic hydroxyl groups. Chin. Med. 2018, 13, 51. [CrossRef] [PubMed]

19. Shimizu, K.; Kondo, R.; Sakai, K. Inhibition of tyrosinase by flavonoids, stilbenes and related 4-substituted resorcinols: Structureactivity investigations. Planta Med. 2000, 66, 11-15. [CrossRef]

20. Khatib, S.; Nerya, O.; Musa, R. Chalcones as potent tyrosinase inhibitors: The importance of a 2,4-substituted resorcinol moiety Bioorg. Med. Chem. 2005, 13, 433-441. [CrossRef]

21. Kim, D.; Park, J.; Kim, J. Flavonoids as mushroom tyrosinase inhibitors: A fluorescence quenching study. J. Agric. Food Chem. 2006, 54, 935-941. [CrossRef] [PubMed]

22. Kumar, G.S.; Jayaveera, K.N.; Kumar, C.K.A.; Sanjay, U.P.; Swamy, B.M.V.; Kumar, D.V.K. Antimicrobial effects of Indian medicinal plants against acne-inducing bacteria. Trop. J. Pharm. Res. 2007, 6, 717-723. [CrossRef]

23. Athikomkulchai, S.; Watthanachaiyingcharoen, R.; Tunvichien, S.; Vayumhasuwan, P.; Karnsomkiet, P.; Sae-Jong, P.; Ruangrungsi, N. The development of anti-acne products from Eucalyptus globulus and Psidium guajava oil. J. Health Res. 2008, 22, 109-113.

24. Okunji, C.; Komarnytsky, S.; Fear, G.; Poulev, A.; Ribnicky, D.M.; Awachie, P.I.; Ito, Y.; Raskin, I. Preparative isolation and identification of tyrosinase inhibitors from the seeds of Garcinia kola by high-speed counter-current chromatography. J. Chromatogr. A 2007, 1151, 45-50. [CrossRef]

25. Kiken, D.A.; Cohen, D.E. Contact dermatitis to botanical extracts. Am. J. Contact Dermat. 2002, 13, 148-152. [PubMed]

26. Gotoh, T.; Koyama, T.; Ogura, K. Farnesyl diphosphate synthase and solanesyl diphosphate synthase reactions of diphosphatemodified allylic analogs: The significance of the diphosphate linkage involved in the allylic substrates for prenyltransferase. J. Biochem. 1992, 112, 20-27. [CrossRef]

27. Kim, Y.J.; Uyama, H. Tyrosinase inhibitors from natural and synthetic sources: Structure, inhibition mechanism and perspective for the future. Cell Mol. Life Sci. 2005, 62, 1707-1723. [CrossRef]

28. Ye, Y.; Chou, G.X.; Mu, D.D.; Wang, H.; Chu, J.H.; Leung, A.K. Screening of Chinese herbal medicines for antityrosinase activity in a cell free system and B16 cells. J. Ethnopharmacol. 2010, 129, 387-390. [CrossRef]

29. Likhitwitayawuid, K.; Sritularak, B.; De-Eknamkul, W. Tyrosinase inhibitors from Artocarpus gomezianus. Planta Med. 2000, 66, 275-277. [CrossRef]

30. Costin, G.E.; Hearing, V.J. Human skin pigmentation: Melanocytes modulate skin color in response to stress. FASEB J. 2007, 21, 976-994. [CrossRef]

31. Chang, T.S. Natural melanogenesis inhibitors acting through the down-regulation of tyrosinase activity. Materials 2012, 5 , 1661-1685. [CrossRef]

32. Niu, C.; Aisa, H.A. Upregulation of melanogenesis and tyrosinase activity: Potential agents for vitiligo. Molecules 2017, $22,1303$. [CrossRef] 
33. Xie, Y.; Yang, W.; Tang, F.; Chen, X.; Ren, L. Antibacterial activities of flavonoids: Structure-activity relationship and mechanism. Curr. Med. Chem. 2015, 22, 132-149. [CrossRef]

34. Adamczak, A.; Ożarowski, M.; Karpinski, T.M. Antibacterial activity of some flavonoids and organic acids widely distributed in plants. J. Clin. Med. 2020, 9, 109. [CrossRef] [PubMed]

35. Cushnie, T.P.T.; Lamb, A. Antimicrobial activity of favonoids. Int. J. Antimicrob. Agents 2005, 26, 343-356. [CrossRef]

36. Fletcher, J.N. Isolation, Identification, and Biological Evaluation of Potential Flavor Modulatory Flavonoids from Eriodictyon Californicum. Ph.D. Thesis, The Ohio State University, Columbus, OH, USA, 2011.

37. Lan, W.C.; Tzeng, C.W.; Lin, C.C.; Yen, F.L.; Ko, H.H. Prenylated flavonoids from Artocarpus altilis: Antioxidant activities and inhibitory effects on melanin production. Phytochemistry 2013, 89, 78-88. [CrossRef] [PubMed]

38. Dej-adisai, S.; Meechai, I.; Puripattanavong, J.; Kummee, S. Antityrosinase and antimicrobial activities from Thai medicinal plants. Arch. Pharm. Res. 2014, 37, 473-483. [CrossRef] [PubMed]

39. Dávila, M.; Sterner, O.; Hinojosa, N. Flavonoids from Baccharis polycephala Weddell. Rev. Boliv. Quim. 2013, 30, 137-141.

40. Sritularak, B. Chemical constituents of Artocarpus lakoocha and A. gomezianus. Master's Thesis, Chulalongkorn University, Bangkok, Thailand, 1998.

41. Sritularak, B.; De-Eknamkul, W.; Likhitwitayawuid, K. Tyrosinase inhibitors from Artocarpus lakoocha. Thai J. Pharm Sci. 1998, 22, 149-155.

42. Skehan, P.; Storeng, R.; Scudiero, D.; Monks, A.; McMahon, J.; Vistica, D. New colorimetric cytotoxicity assay for anticancer-drug screening. J. Natl. Cancer Inst. 1990, 82, 1107-1112. [CrossRef]

43. Takahashi, H.; Parsons, P.G. Rapid and reversible inhibition of tyrosinase activity by glucosidase inhibitors in human melanoma cells. J. Investig. Dermatol. 1992, 98, 481-487. [CrossRef] [PubMed]

44. Hunt, G.; Todd, C.; Cresswell, J.E.; Thody, A.J. Alpha-melanocyte stimulating hormone and its analogue Nle4DPhe7 alpha-MSH affectmorphology, tyrosinase activity and melanogenesis in cultured human melanocytes. J. Cell Sci. 1994, 107, 205-211. [CrossRef] [PubMed]

45. Lorian, V. Antibiotics in Laboratory Medicine, 5th ed.; Lippincott Williams \& Wilkins: Philadelphia, PA, USA, 2005.

46. Clinical and Laboratory Standards Institute (CLSI). Methods for Dilution Antimicrobial Susceptibility Testes for Bacterial that Grow Aerobically; Approved Standards, 7th ed.; Clinical and Laboratory Standards Institute (CLSI): Wayne, PA, USA, 2006. 